\title{
Análise de vinhetas sobre a planificação de sequência didática
}

\author{
João Antonio dos Santos de Lima" \\ Lídia Stutz" \\ Gerson Anschau Poleze $e^{\text {sen }}$
}

\section{Resumo}

Esta pesquisa visa a analisar vinhetas produzidas no estágio supervisionado de uma turma de terceiro ano de Letras Inglês, nas quais um aluno-professor registrou suas experiências vivenciadas durante a planificação de uma sequência didática (SD). A ancoragem teórica provém do interacionismo sociodiscursivo e de sua proposta de transposição didática de gêneros e da pesquisa narrativa. A geração de dados foi realizada entre os meses de abril a junho de 2019, mediante o registro e seleção de vinhetas sobre produção de SDs. Consideramos os aspectos contextuais, segmentos temáticos, vozes e modalizações. Os resultados apontam que as atividades de estágio de modo geral e o trabalho de reflexividade por meio de vinhetas narrativas oportunizaram um trabalho mais específico considerando os saberes da planificação das aulas.

Palavras-chave: Vinhetas. Estágio supervisionado. Sequência didática. Transposição didática de gêneros. Planificação.
Possui graduação em Letras - Língua Portuguesa pela Universidade Estadual do Centro-Oeste (2013). Tem experiência na área de Letras, com ênfase em Letras. Especialista em Docência no Ensino Superior pela Unicentro. E-mail: joaoantonio_lima@hotmail.com

** Possui graduação em Letras Português Inglês pela Universidade Estadual do Centro-Oeste (1993), mestrado em Letras (Inglês e Literatura Correspondente) pela Universidade Federal de Santa Catarina (2005), doutorado em Estudos da Linguagem pela Universidade Estadual de Londrina (2012), com estágio doutoral realizado na Universidade de Genebra (Bolsa Capes-DS-2010) e pós-doutorado em Estudos da Linguagem na Universidade Estadual de Londrina (2017). Professora Adjunta Nível D do Departamento de Letras e do Mestrado em Letras na Universidade Estadual do Centro-Oeste. É líder do grupo de pesquisa Gêneros Textuais e Práxis Docente - Unicentro e integrante do grupo de pesquisa Linguagem e Educação da UEL. Atuou como coordenadora do Subprojeto Pibid Letras Inglês de 2012-2018. De agosto de 2017 a janeiro de 2019, coordenou o Programa de Pós-Graduação Stricto Sensu em Letras (Nível Mestrado) na Unicentro. Atua no Estágio Supervisionado em Língua Inglesa e tem experiência na área de Linguística Aplicada à Língua Inglesa, com ênfase nos seguintes temas: ensino de Línguas, interacionismo sociodiscursivo, gêneros textuais, saberes docentes, formação de professores, reflexividade e gestos didáticos. E-mail: lidia.stutz@gmail.com

*** Membro do Conselho Municipal de Acompanhamento e de Controle Social do Fundo de Manutenção da Educação Básica e de Valorização dos Profissionais do Magistério (Fundeb), para o biênio 2021/2022, Guarapuava, PR. Mestre em Letras - Interfaces entre Língua e Literatura, na linha de pesquisa Linguagens, Leitura e Interpretação, pelo Programa de Pós-Graduação Stricto Sensu em Letras da Universidade Estadual do Centro-Oeste do Paraná (2021), sob orientação da Profa. Dra. Lidia Stutz. Especialista em Ensino da Língua Portuguesa e Inglesa e especialista em Gestão Educacional: Direção, Coordenação e Supervisão, ambas pela Faculdade UNIBF - Paraíso do Norte (2021). Em 2018, foi um dos 14 premiados no estado do Paraná para bolsa de estudos da SETI/Languages Canada, no East Coast Language College Halifax - Província de Nova Escócia. Aperfeiçoamento como Pesquisador em Ciências da Educação - IFMG, Campus Arcos. Graduou-se em Pedagogia pela Universidade para o Desenvolvimento do Estado e da Região do Pantanal, Campo Grande (2013). É membro do Grupo de Estudos Gêneros Textuais e Práxis Docente, junto ao CNPq (dgp.cnpq.br/dgp/ espelhogrupo/8458521720239451) e vinculado ao Laboratório de Linguagem, Variação e Ensino (LIVE - PPGL/Unicentro). Realiza pesquisas na área de gêneros de texto com foco em modelização didática e construção de sequências didáticas para ensino de língua inglesa na educação infantil. E-mail: gersonap92@gmail.com

Data de submissão: set. 2020 - Data de aceite: nov. 2020 http://dx.doi.org/10.5335/rdes.v16i3.11497 


\section{Introdução}

Considerando nossa preocupação com as práticas reflexivas sobre o trabalho do professor em formação inicial e tendo em vista que "a formação de professores, inicial e continuada, encontra na prática investigativa um alicerce para crítica, reflexão, aprofundamento de conhecimentos teóricos e crescimento profissional" (STUTZ, 2012, p. 57), buscamos produzir o presente trabalho. Nosso objetivo é analisar vinhetas, concebidas como um instrumento para a reflexividade que permite desvelar as operações psíquicas da transposição didática (TD) de gêneros, produzidas durante o processo de planificação de uma sequência didática (SD) como instrumento de formação.

O nosso trabalho constituiu parte dos estudos de um aluno-professor, coautor deste estudo, desenvolvidos na matéria de Estágio Supervisionado no curso de Letras Inglês de uma universidade pública. Para fortalecer os saberes sobre a planificação ${ }^{1}$, o aluno-professor, durante a participação no processo de construção de uma SD, produziu vinhetas sobre o trabalho de planificação, contemplando a pertinência e a relevância das escolhas do gênero, dos textos, das atividades e das necessidades de refacção. O período da geração dos dados se deu de maio a junho de 2019.

A base teórica que fundamenta nosso estudo alia-se aos pressupostos teórico-metodológicos do interacionismo sociodiscursivo (ISD) (BRONCKART, 1999/2007,
2006, 2008), à proposta de TD de gêneros (DOLZ, 2016; CRISTOVÃO, 2009; MACHADO; CRISTOVÃO, 2006; DOLZ; NOVERRAZ; SCHNEUWLY, 2004) e à pesquisa narrativa (CLANDININ; CONNELLY, 2011). Apoiamo-nos no propósito de uma aprendizagem do aluno/professor advinda de uma ação consciente, planejada e bem elaborada e que vise a transformação do indivíduo (STUTZ; CARNEIRO, 2015, p. 430) e consequentemente de suas práticas em sala de aula.

A geração dos dados surgiu de três vinhetas, selecionadas dentre seis produzidas pelo aluno-professor ao realizar a formação em alternância no meio acadêmico e escolar, as quais foram registradas em manuscritos e também digitalizadas e salvas no computador pessoal do aluno-professor.

Buscamos com este estudo elucidar e entender "o que as vinhetas evidenciam sobre o processo de planificação com SDs?". Para tanto, a fim de guiar o leitor, explicitamos que este artigo está dividido em quatro partes. Primeiramente, apresentamos a fundamentação teórica, na sequência trazemos brevemente a descrição da metodologia utilizada, na terceira parte nos debruçamos sobre a análise das vinhetas e para encerrar apresentamos as considerações finais.

\section{Fundamentação teórica}

Dividimos nossa fundamentação teórica em duas subseções, a primeira trata 
da formação de professores, pesquisa narrativa e do instrumento vinhetas e a segunda da TD de gêneros de texto e planificação de aulas.

\section{Formação de professores, planificação de aulas e vinhetas}

A formação de professores se estabelece de forma concreta - em forma de práxis - à medida que os profissionais são capazes de refletir e tecer relações teórico-práticas sobre a atividade docente. Partimos da ideia de reflexão de trabalho como sendo essencial na busca de uma "construção/transformação de saberes docentes necessários para melhorar a inserção dos futuros profissionais de língua inglesa no ambiente de trabalho" (STUTZ; CRISTOVÃO, 2019, p. 626).

Consideramos a formação inicial a primeira etapa para o desenvolvimento profissional, o qual se prolonga ao longo da vida, já que a docência pressupõe estudo, aperfeiçoamento profissional e pesquisa em virtude da realidade social em constante mudança a que está inserida (MAGALHÃES, 2019). Portanto, se nossos esforços são de observar cientificamente os saberes e capacidades indispensáveis ao trabalho docente, devemos iniciar essa observação com suporte na análise reflexiva que o professor faz da sua prática. Nas palavras de Stutz (2012, p. 57),
[...] a pesquisa voltada à reflexão sobre a ação leva o professor a tomar consciência da prática e torna-se uma oportunidade para construir conhecimento e desenvolvimento.

Dessa forma, o professor realmente engajado em sua prática deve estar ciente de que precisa refletir sobre seu trabalho, seguindo, de acordo com Stutz e Carneiro (2015, p. 430), algumas questões:

O que o professor pensa que sabe? Como ele avalia sua ação e a ação dos demais actantes, copartícipes do agir educacional? De que maneira o profissional acumula, prioriza e assume determinados saberes como recursos para sua conduta?.

Essas perguntas são fundamentais para a discussão da relação entre a prática e a formação profissional observando os saberes e capacidades indispensáveis ao trabalho docente.

Hofstetter e Schneuwly (2009) categorizam os saberes da formação em saberes a ensinar e para ensinar, sendo os primeiros destinados aos saberes sobre o conteúdo da disciplina que, em nosso caso, voltam-se à língua inglesa e as especificidades do gênero a ser ensinado. Já os saberes para ensinar dizem respeito à metodologia utilizada. Com base nessa categorização e no Portfólio Europeu de Formação de Professores (PEPELF), Stutz (2012) propôs sete categorias, as quais são: saberes sobre o contexto, saberes sobre a planificação, saberes sobre recursos didáticos, saberes sobre a metodologia, saberes sobre a prática da regência, saberes sobre autonomia e saberes sobre a avaliação. 
Os estudos de doutoramento de Lanferdini (2019, p. 334) apresentam sete dimensões do planejamento, que são: "social/interacional, prefigurativa ou autoprescritiva, transpessoal, conflituosa, cognitiva, de reflexividade e afetiva", as quais utilizamos em nossa análise.

Em busca de uma ferramenta que registrasse os momentos da planificação das aulas, encontramos respaldo no processo de aprendizagem denominado Pesquisa Narrativa. De acordo com Clandinin e Connelly (2011, p. 18), "pesquisa narrativa é um processo dinâmico de viver e contar histórias, e reviver e recontar histórias, não somente aquelas que os participantes contam, mas aquelas também dos pesquisadores". Assim, a pesquisa narrativa demanda ser entendida como um meio de compreensão da experiência humana, pois refere-se a um estudo de histórias vividas e contadas. A pesquisa narrativa, segundo os autores, pode ser realizada por meio de entrevistas, diários, autobiografias, gravação de narrativas orais, narrativas escritas, notas de campo e com o uso de gravações em áudio ou em vídeo ou descrições por escrito de um determinado tema. Utilizamos em nosso trabalho as narrativas escritas, que serão apresentadas por meio do instrumento vinheta.

\section{Vinhetas são}

[...] cenários ou histórias curtas em forma escrita ou pictórica que os participantes podem comentar e cuja característica principal é explorar os sistemas de crenças subjetivas dos participantes (HOELZ; BATAGLIA, 2015, p. 64).
Em Lieberman (1987), o uso de vinhetas tem a função de avaliar a dinâmica do trabalho do professor, as sutilezas que nem sempre se tornam perceptíveis aos olhos do avaliador. Essas ferramentas seguem passos pré-estabelecidos, sendo: descrição e reflexão sobre o contexto, expectativas do enunciatário, pessoas envolvidas, o que foi realizado, o que aconteceu, o impacto, o porquê do acontecimento e outros comentários. De acordo com Schratz et al. (2013), as vinhetas comumente são usadas para descrições e narrativas densas de eventos, são formas de capturar empiricamente suas próprias experiências.

Vinhetas são consideradas efetivas no meio de formação inicial por diversas razões: a) pela facilidade de construção; b) por proverem foco e estímulo de discussão; c) pela possibilidade de utilizar tópicos muito variados; d) pela utilização em grupos ou de forma individual; e) por refletirem situações da vida real. Amparados nessa concepção, em nosso estudo utilizar-nos-emos do instrumento vinhetas como meio de compreender a planificação de uma SD realizada por um aluno-professor.

A alternativa que utilizamos para a apreensão de saberes da planificação das aulas na formação de professores de língua inglesa é a proposta de TD de gêneros. Os saberes da planificação que buscamos analisar por meio das vinhetas convergem com os demais saberes em prol dessa ação de engenharia didática de construção de SDs. Podemos aqui fazer 
uma analogia dessa engenharia de planificação como um quebra-cabeça em que as peças são esse conjunto de saberes sobre o contexto, sobre as metodologias, sobre a avaliação, sobre as aulas, entre outros que vão possibilitar essa construção.

Esses saberes docentes precisam ser fortalecidos na formação, tendo em nosso estudo a TD de gêneros como um solo fértil para alcançar esse fim. Na próxima seção trazemos a proposta de TD sob as lentes do ISD.

\section{Transposição didática de gêneros de texto}

Nos estudos do ISD, a linguagem é social, envolve uma interação entre indivíduos, se faz presente pelo discurso e é por meio da interação social que o ser humano aprende e se desenvolve. Nesse meio, o ISD defende a tese de que "o comportamento humano é o resultado de uma socialização particular capacitada por meio da emergência histórica de instrumentos semióticos" (BRONCKART, 1999, p. 78). Dessa forma, nos tornamos agentes comunicativos nas mais diversas interações de uso da linguagem, que consistem em "produzir, compreender, interpretar e/ou memorizar um conjunto organizado de enunciados orais ou escritos" (DOLZ-MESTRE; PASQUIER; BRONCKART, 1993/2017, p. 161-162).

Ao contemplar o viés sociointeracionista vigotskiano e o construto do ISD,
Cristovão (2001) explicita que a língua é um agir que se fundamenta no discurso e é nas atividades sociais, em uma formação social, que se desenvolvem as ações de linguagem, ou seja, uma interação entre o sujeito e o meio. A pesquisadora reitera ainda que a "ação de linguagem integraria os parâmetros do contexto de produção e do conteúdo temático que $o$ agente-produtor de um texto mobiliza" (CRISTOVÃO, 2001, p. 19).

A partir da integração desses parâmetros dos quais os sujeitos interlocutores participam, mobilizamos diferentes saberes de ordem cognitiva, linguística e social, dentre essas, a escolha do gênero adequado e significativo à situação na qual interagimos. Nossa interação social toma como base modelos pré-determinados de textos em todas as situações de comunicação, os quais são chamados gêneros de texto ${ }^{2}$ (CRISTOVÃO, 2009).

Nos estudos do ISD a linguagem que se materializa pelos gêneros é crucial para que ocorra a interação humana. Schneuwly (2004, p. 23) nos diz que "o gênero é um instrumento" e que tais instrumentos determinam no sujeito o "seu comportamento, guiam-no, afinam e diferenciam sua percepção da situação na qual ele é levado a agir". O autor determina como parâmetros para a escolha dos gêneros a finalidade do uso, os destinatários e o conteúdo temático do texto. Ou seja, assim que o sujeito escolhe o gênero que será utilizado 
durante a interação, ele o adapta e põe em uso. Portanto, é papel dos gêneros é fazer a mediação entre os indivíduos em uma situação de comunicação. Assim, consideramos o gênero de texto como instrumento para realizar as interações e as ações, sendo, portanto, também instrumento de apreensão de saberes e de desenvolvimento.

Pensar o ensino da língua por meio de gêneros acarreta a necessidade de se dispor de uma ferramenta utilizadora de métodos descritivos e analíticos que apresente as dimensões ensináveis do gênero a ser transposto para a sala de aula. Essa TD do gênero se justifica pela conjuntura de que a apropriação desse instrumento possibilita "práticas docentes adequadas ao contexto escolar e ao meio social dos alunos" (PAEZ; STUTZ, 2015, p. 2). Nesse cenário, se faz necessário "transformar o conteúdo a ser ensinado, para que se enquadre ao contexto e conhecimentos do aluno" (PAEZ; STUTZ, 2015, p. 2), surgindo assim a necessidade de uma TD, a qual consiste em transformar o objeto de ensino em objeto ensinado.

Para podermos fazer a TD de gêneros textuais, necessitamos da construção de um modelo didático (MD), o qual traz as dimensões do gênero que podem ser abordadas em uma SD. De Pietro e Schneuwly (2003) afirmam que o MD é um instrumento que tem a função de explicitar e sistematizar o conteúdo do gênero de texto que será utilizado para a produção de uma SD. Ou seja, é a partir do MD que é construída a SD, a qual se constitui de um conjunto de atividades para os alunos. Pontuamos que em nosso estudo, as dimensões ensináveis do $\mathrm{MD}$ de nursery rhymes (NR) de Poleze e Stutz (2019) contribuíram para nortear a construção da SD.

As SDs são definidas por Dolz, Noverraz e Schneuwly (2004, p. 97) como "um conjunto de atividades escolares organizadas, de maneira sistemática, em torno de um gênero textual oral ou escrito". Na proposta clássica dos autores, a SD é composta de apresentação da situação, avaliação inicial, um conjunto de módulos de atividades e a avaliação final. A fim de planificar a proposta, o professor atua como um engenheiro didático que precisa considerar as prescrições governamentais, a escolha de gêneros compatíveis quanto às dimensões ensináveis, que, por sua vez, possibilitem construir atividades com o propósito de fortalecer as capacidades de linguagem dos alunos.

Ou seja, a SD é um dispositivo didático que, de forma progressiva, reúne os aspectos que se pretende ensinar sobre determinado gênero, com vistas a tornar o aprendiz proficiente no uso da língua e, assim, possa engajar-se nas atividades de linguagem que o gênero possibilita. Para isso, explicita as capacidades de linguagem que estão ali postas e devem ser desenvolvidas, de modo que o aluno possa agir por meio da linguagem e 
"mobilizar os conhecimentos que temos e operacionalizar a aprendizagem" (CRISTOVÃO, 2009, p. 319). Cabe destacar que são elas: capacidades de ação, capacidades discursivas e capacidades linguístico-discursivas (DOLZ-MESTRE; PASQUIER; BRONCKART, 1993, 2017). Estas foram as três inicialmente propostas pelos estudiosos da Suíça, contudo, no contexto brasileiro, o conceito foi ampliado e cabe-nos destacar outras capacidades, especialmente as capacidades de significação propostas por Cristovão e Stutz (2011). Outras ainda se fazem presentes, como as capacidades multissemióticas, propostas no grupo de pesquisa Linguagem e Educação ${ }^{3}$, da Universidade Estadual de Londrina e apresentadas no trabalho de Lenharo (2016), e digitais, discutidas no grupo de pesquisa Gêneros Textuais e Práxis Docente $^{4}$, da Universidade Estadual do Centro-Oeste, e que Cacilho (2016) trouxe em sua dissertação de mestrado.

A planificação de SD que contemplamos como atividade da formação inicial é uma complexa tarefa que envolve, portanto, por parte do aluno-professor essas capacidades de linguagem apresentadas, bem como a compreensão dos obstáculos que se fazem presentes na apreensão dos objetos de ensino por parte dos alunos quanto à compreensão e produção de um gênero. Consideramos então que os saberes sobre a planificação envolvem um conjunto de capacidades docentes que precisam considerar o perfil e conhecimentos dos alunos da escola para poder traçar e "identificar os objetivos de aprendizagem", "planificar os conteúdos da aula" (STUTZ, 2012, p. 84) e organizar toda a proposta desse conjunto de atividades de forma sequencial e progressiva, por meio dos módulos que constituem a SD. Na próxima seção descrevemos 0 percurso da metodologia deste estudo.

\section{Metodologia}

Em nossa pesquisa selecionamos o gênero textual NR como instrumento de ensino de Língua Inglesa. Ajustificativa para a escolha desse gênero é a de que as NR estão fortemente relacionadas ao mundo lúdico e musical (POLEZE; STUTZ, 2019). Assim, sua inserção no meio escolar possibilita a apreensão linguageira, desenvolvimento da criatividade, de fatores motores, afetivos, de socialização e interação.

Nossa pesquisa advém da participação de uma aluno-professor e apoia-se nas lentes do ISD e da didática das línguas, que contemplam os saberes da planificação.

Firmando-nos na pesquisa narrativa, utilizamos o instrumento vinhetas para relatar a planificação de SDs realizadas pelo aluno-professor durante todo o procedimento de produção, adequação e refacção. Procuramos desvelar o que as vinhetas evidenciam sobreo processo de 
planificação, ou seja, como ocorreu a pertinência e a relevância da escolha do gênero de texto e dos textos, a construção das atividades de cada módulo, as necessidades de refacção na construção das SDs e as inquietações, tensões e desafios durante o período de produção do material didático.

A fim de compreender o processo de construção da SD, selecionamos uma vinheta no início da planificação outra durante o processo e uma na finalização. Buscamos por meio desse percurso desvelar os saberes e capacidades docentes.

Para análise das vinhetas seguimos as categorias de análise de textos do ISD, propostos por Bronckart (1999). Primeiramente, fazemos um levantamento do contexto de produção dos textos (físico e socio-subjetivo), ou seja, das condições de produção, as quais envolvem o momento socio-histórico de produção do texto, o levantamento do produtor e receptor do texto, o local e período da produção, a posição social ocupada pelo produtor e pelo receptor e a função social do texto (BRONCKART, 1997/2007; MACHADO, 2005).

Em nosso trabalho, também buscamos compreender como as vinhetas se configuram por meio da análise de segmentos de orientação temática (SOT) e de segmentos de tratamento temático (STT) (BRONCKART, 2008), que possibilitam compreender a organização e o encadeamento do conteúdo temático, a responsabilidade enunciativa que é analisada pelas vozes (vozes de perso- nagem, vozes sociais e voz do autor) e as avaliações sobre as temáticas, através das modalizações do enunciado (lógicas, deônticas, apreciativas e pragmáticas). Esses critérios possibilitam compreender os desafios e tensões narrados nas vinhetas construídas pelo aluno-professor e as confrontações e comparações que possam ser estabelecidos com os saberes e as capacidades docentes. Passemos, então, a analisar as vinhetas produzidas durante o processo de planificação de SD como instrumento de formação.

\section{Análise}

A nossa análise sobre as vinhetas busca compreender como ocorreu o processo de planificação de uma SD sobre o gênero NR, produzidas por um aluno-professor do terceiro ano do curso de Letras inglês, o qual assume o papel social de enunciador do texto. As vinhetas tinham como objetivo explicitar como ocorre o processo de construção das SD com NR.

O público-alvo, primeiramente, são colegas alunos-professores durante a socialização em sala de aula e a professora de Estágio Supervisionado na apresentação dos relatórios e nas orientações da Iniciação Científica. Em um segundo momento, o público-alvo é a comunidade acadêmica que terá acesso ao artigo, os quais assumem o papel social de destinatários do texto.

O período de construção do material foi de maio a julho de 2019, momento 
concomitante com a construção da SD, que trata do processo de produção, desde as escolhas iniciais até o processo de readequação e da versão final da SD. Quanto à situação de produção do documento, tal momento se deu na casa do aluno-professor e no meio acadêmico de uma universidade pública do centro-oeste do Paraná. As vinhetas foram produzidas tendo como propósito refletir sobre o processo de formação por meio da planificação de SD.

A primeira vinheta selecionada, que tem por título "Um amontoado de atividades aleatórias", ilustra a experiência do aluno-professor em um primeiro contato com as teorias do ISD e a produção de uma SD. À vista disso, os SOT identificados em nossa análise foram "Primeira tentativa", "Preparando o material" e "As dúvidas continuam". Os SOTs e STTs desenvolvidos apresentamos no Quadro 1 :

Quadro 1 - SOTs/STTs da vinheta: "Um amontoado de atividades aleatórias"

\begin{tabular}{|c|c|}
\hline $\begin{array}{l}\text { Segmento de } \\
\text { Orientação } \\
\text { Temática (SOT) }\end{array}$ & $\begin{array}{c}\text { Segmento de Tratamento } \\
\text { Temático } \\
\text { (STT) }\end{array}$ \\
\hline $\begin{array}{l}\text { 1) Primeira } \\
\text { tentativa }\end{array}$ & $\begin{array}{l}\text { 1.a) Início dos trabalhos } \\
\text { 1.b) Aplicação } \\
\text { 1.c) Informações novas } \\
\text { 1.d) Fichamento da teoria }\end{array}$ \\
\hline $\begin{array}{l}\text { 2) Preparando o } \\
\text { material }\end{array}$ & $\begin{array}{l}\text { 2.a) Assimilação de informações } \\
\text { 2.b) Elaboração das aulas } \\
\text { 2.c) Ferramentas } \\
\text { 2.d) Seleção de material }\end{array}$ \\
\hline $\begin{array}{l}\text { 3) As dúvidas } \\
\text { continuam }\end{array}$ & $\begin{array}{l}\text { 3.a) Indagações e incertezas } \\
\text { 3.b) Inserção de atividades } \\
\text { 3.c) Seleção de exercícios } \\
\text { 3.d) Pensando nos alunos }\end{array}$ \\
\hline
\end{tabular}

Fonte: elaboração dos autores.
A primeira vinheta selecionada apresenta, em seu todo, um conjunto de informações que apontam uma introdução a novos conhecimentos, o desconforto com a novidade proposta durante a elaboração do material e a preocupação com a apreensão do novo conteúdo pelos alunos que serão alvo da implementação da SD.

Ao observarmos os STTs, percebemos que as tensões discursivas que se desenrolam na vinheta referem-se à apreensão de novas aprendizagens pelo narrador, neste caso a proposta com as SDs. Essa nova proposta gera dúvidas, incertezas e muitos questionamentos devido a ser algo ainda desconhecido pelo aluno-professor naquele momento. Dessa maneira, surge um certo desconforto quanto à aceitação do que se é apresentado e uma das preocupações é se haverá um bom resultado quando utilizada na prática em sala de aula.

A respeito do SOT "Primeira tentativa”, os STTs pautados dizem respeito ao (1.a) início dos trabalhos, (1.b) a aplicação, (1.c) as informações novas e (1.d) o fichamento da teoria. Em vista disso, entendemos que o aluno professor descreve seu processo de aquisição das novas informações de aprendizagem da proposta com SDs demonstrando que, devido ao fato de ser o seu primeiro contato com a SD, surge a necessidade de fixar, por meio de anotações o conteúdo a ser aprendido. Isso se dá pelo fato de que, quando tomamos nota do que está 
sendo ensinado, podemos ter suporte seguro para futuras consultas ou revisão de material para fixação de aprendizado.

O SOT "Preparando o material" e o SOT "As dúvidas continuam" trazem os STTs (2.a) assimilação de informações, (2.b) elaboração das aulas, (2.c) ferramentas e (2.d) seleção de material e os STTs (3.a) indagações e incertezas, (3.b) inserção de atividades, (3.c) seleção de exercícios e (3.d) pensando nos alunos. Estes segundo e terceiro momentos são analisados conjuntamente por tratarem de assuntos semelhantes. Neles, vemos o aluno-professor fazendo a descrição de uma primeira produção da SD e sua angústia quanto a estar fazendo corretamente o processo de elaboração e seleção de material. Aqui vemos que o fluxo de aprendizagem é contínuo e as dúvidas mostram a apreensão gradual que nos primeiros passos do trabalho não puderam ainda solidificar os saberes sobre a construção/planificação da SD. É preciso criar estratagemas para que se supere tais desafios. Neste caso, a estratégia para conseguir produzir algo concreto foi reservar uma boa quantidade de material para depois selecionar o que poderia ser útil.

Em relação a análise das vozes presentes no texto, observamos nesta vinheta a presença de três vozes: a voz de autor empírico na posição social de aluno-professor, a voz de aluno-professor como voz social pertencente de um coletivo de alunos-professores de Língua Inglesa e a voz da professora. O aluno-professor é quem narra tudo que é dito, marcando assim a sobreposição do enunciador para com seus enunciatários, o que lhe confere ter a voz predominante no texto, sendo classificada, conforme propõe Bronckart (1999), como sendo a voz do autor. A voz da turma e da professora, apesar de serem de outras pessoas têm implicação direta nas informações do texto e, assim sendo, podem ser classificadas como voz dos personagens. Nos excertos abaixo, podemos observar em negrito a voz do autor, a qual predomina no texto, e também as modalizações encontradas na vinheta:

Excerto 1:

[...] decidi iniciar meus trabalhos com a produção da SD. Na segunda-feira anterior, na aula de Estágio, eu estava de cabelo em pé com tantas informações novas a respeito dessa atividade. Por isso, resolvi fazer um fichamento do documento sobre SDs que a professora havia nos fornecido. [...] fiz o fichamento na sexta-feira de manhã.

No trecho selecionado, o uso das modalizações pelos verbos decidi, resolvi e fiz indicam ações concretas efetivadas pelo aluno-professor, o autor da vinheta. De acordo com as funções das modalizações propostas por Bronckart (1999), as modalizações designadas podem ser classificadas como modalizações lógicas.

As modalizações registradas apresentam situações didáticas específicas relacionadas com a habilidade de pro- 
dução de SDs em que o aluno-professor é confrontado com um problema prático que exige dele a necessidade de fazer um conjunto de decisões. O primeiro conjunto de decisões está relacionado ao início dos estudos do aluno-professor com o ISD. O segundo conjunto está relacionado ao registro de textos para futura exploração e a terceira está relacionada à materialização de seus estudos na planificação da SD.

Já a modalização eu estava de cabelo em pé serve para indicar o sentimento de inquietação do aluno-professor ao se deparar com a nova proposta didática. Seguindo os preceitos das mobilizações, classificamos o fragmento como modalização apreciativa, por advir do mundo subjetivo e sinalizar as tensões e o desconforto gerados pela apreensão dos novos saberes.

Nessa vinheta, não identificamos a presença de outras modalizações. Assim sendo, a vinheta "Um amontoado de atividades aleatórias" nos leva a concluir que uma nova proposta de ensino e aprendizagem pode causar muitos temores a um aluno-professor em sua formação inicial e até certos conflitos internos, tais como incertezas e inseguranças. Essa inquietação se dá seja pela compreensão ou não da proposta, seja no momento de construção da SD e até mesmo quando começa a pensar no momento futuro em que o aluno-profes- sor estará regendo uma turma em uma sala de aula.

A segunda vinheta a ser analisada tem por título "FIQUEI ENCUCADO". Ela demonstra uma fase mais avançada do trabalho do aluno-professor com as SDs. Nesta vinheta vemos a perplexidade do narrador ao se deparar com a quantidade de novas informações e vemos também a sua importante tomada de decisão em buscar noutras fontes a possibilidade de sanar suas dúvidas, como a consulta ao orientando de mestrado que apresentou parte de um estudo aos alunos do estágio. Isto posto, conferimos agora os SOTs identificados em nossa análise, os quais são nomeados como: "Buscando novas perspectivas" e "Assimilando informações". Os SOTs e STTs desenvolvidos apresentamos no Quadro 2:

Quadro 2 - SOTs/STTs da vinheta: "FIQUEI ENCUCADO"

\begin{tabular}{|c|c|}
\hline $\begin{array}{l}\text { Segmento de } \\
\text { Orientação } \\
\text { Temática (SOT) }\end{array}$ & $\begin{array}{l}\text { Segmento de Tratamento } \\
\text { Temático } \\
\text { (STT) }\end{array}$ \\
\hline $\begin{array}{l}\text { 1) Buscando } \\
\text { novas } \\
\text { perspectivas }\end{array}$ & $\begin{array}{l}\text { 1.a) Apresentando propostas } \\
\text { 1.b) Comparando ideias } \\
\text { 1.c) Buscando conselhos } \\
\text { 1.d) Expondo dúvidas }\end{array}$ \\
\hline $\begin{array}{l}\text { 2) Assimilando } \\
\text { informações }\end{array}$ & $\begin{array}{l}\text { 2.a) Revisando o texto } \\
\text { 2.b) Reorganizando ideias } \\
\text { 2.c) Comparando explicações } \\
\text { 2.d) Conflito interno } \\
\text { 2.e) Novas dúvidas }\end{array}$ \\
\hline
\end{tabular}

Fonte: elaboração dos autores. 
Essa vinheta apresenta em seu primeiro SOT, "Buscando novas perspectivas", o empenho do aluno-professor em tentar compreender a nova proposta didática por outros meios, comparando, por exemplo, seus estudos com a apresentação do aluno de mestrado. Essa apresentação ficará mais clara com o excerto apresentado mais à frente.

O aluno-professor descreve ter uma experiência de aprendizagem interessante ao fazer conexões e reconsiderações a respeito de sua própria pesquisa. Isso se evidencia em sua narração no momento em que examina as pesquisas de outra pessoa, a qual vem de um contexto diferente e apresenta novas visões do tema estudado.

Os STTs referentes ao primeiro SOT começam apresentando propostas (1.a), em seguida comparando ideias (1.b), mais adiante buscando conselhos (1.c) e por fim expondo dúvidas (1.d). A princípio, nos STTs "1.a" e "1.b", o aluno-professor recebe as novas informações e relaciona-as com seu contexto, podendo assim direcionar sua atenção para eventos que ocorrem paralelamente ao seu trabalho, mas que conversam entre si. Logo em seguida, nos STTs "1.c" e 1.d", apresenta suas dúvidas em busca de conselhos. Dessa forma, ele consegue apreender e sentir momentos particularmente importantes, o que faz com que mantenha sua mente aberta, permitindo-se ser afetado por essas ocorrências.
O segundo SOT, "Assimilando informações", contempla os STTs revisando o texto (2.a), reorganizando ideias (2.b), comparando explicações (2.c), conflito interno (2.d) e novas dúvidas (2.e). Para a apreensão de informações, fez-se necessário ao aluno-professor voltar aos textos lidos anteriormente e recuperar o que já via estudado para então fazer uma reorganização de ideias. Ao fazer isso, o aluno-professor teve a possibilidade de comparar as explicações recebidas do mestrando com as feitas pela professora. Com as dicas do mestrando, o aluno-professor pode retomar o aprendizado adquirido a partir das informações passadas pela professora, encaixar melhor tais informações em sua construção da SD e, dessa forma, avançar na produção do seu material. Porém, ao observar as dicas e orientações, houve um conflito interno quanto a saber se precisaria se dedicar muito mais a produzir a SD, se teria de receber mais orientações da professora, ou se fazia parte do processo de aprendizagem todas aquelas dúvidas.

Como vimos, o aluno-professor, no papel de pesquisador, em vez de adotar uma postura de pesquisa neutra e indiferente, se apropria dessas novas informações que depois servem de base para suas escritas. Nos excertos abaixo, aprofundamos nossa análise procurando encontrar as vozes e modalizações presentes na vinheta: 
Excerto 2:

Ontem à noite tivemos, na aula de Estágio Supervisionado, a presença de um orientando de mestrado da professora. Ele veio nos apresentar seu trabalho de mestrado que está em andamento e que aborda assuntos reflexivos sobre a prática pedagógica. Vendo na fala dele muito do que a professora já havia nos falado ao longo das aulas, percebi que poderia conectar isso à minha produção de SD. Aproveitei para dialogar com ele e pedir ajuda quanto ao meu trabalho com as SDs. Mostrei minha SD e expus minhas dúvidas, as quais não eram poucas.

As vozes no excerto se mesclam e se alternam na necessidade de explanar sobre a narração na vinheta dos fatos ocorridos durante a socialização em sala sobre a planificação da SD. Percebemos a voz de autor conjunta com a voz de personagem inseridos como alunos no contexto de sala de aula, isso se objetiva pelo uso dos dêiticos tivemos e nos. $\mathrm{O}$ fragmento Ele veio, assim como os fragmentos $d a$ professora e fala dele, todos na terceira pessoa do singular, definem as vozes apresentadas como voz de personagem, que remetem ao mestrando e à professora, ambos copartícipes, que tinham como objetivo mediar os conteúdos sobre a construção da SD aos alunos-professores.

Em seguida, temos o verbo percebi acompanhado da modalização lógica que poderia conectar. Tendo a citação como um todo percebemos que se relaciona à reflexão do narrador a respeito de possíveis correções em seu trabalho. A grande frequência da voz do autor, como nos elementos percebi, aproveitei, mostrei, evidencia a preocupação do aluno-professor em propor soluções para a tensão que surge devido à necessidade de maior aprofundamento nas teorias de estudo.

\section{Excerto 3}

Isso me deixou intrigado, ou, como diz o bordão popular: "Fiquei encucado". Afinal, se eu já havia recebido feedbacks semelhantes, feitos anteriormente pela professora, por que raios eu tinha tanta dificuldade em assimilar essas orientações? Será que era tão difícil colocar em prática tudo isso? Seriam minhas leituras ainda insuficientes? Faltava foco e dedicação? Ou será que tudo isso faz farte do processo de aprendizagem e leva tempo para total assimilação e domínio de conteúdo?

Ao observarmos o excerto, o que nos chama a atenção a princípio é o uso do fragmento me deixou intrigado. Podemos classificar a modalização do fragmento como modalização apreciativa por indicar um sentimento de questionamento acontecendo internamente no aluno-professor quanto à assimilação da forma como proceder na produção de sua SD. Isso se amplifica com o uso da modalização fiquei encucado, uma modalização apreciativa que indica o sentimento de dúvida expresso pelo aluno-professor. Dessa forma, podemos dizer que o autor se encontra em uma fase reflexiva, a qual o faz ter de tomar um caminho de volta ao que já havia recebido de orientações anteriores para que logo em seguida possa avançar e trazer significativos avanços em seu trabalho. Ao questionar suas práticas, 
por exemplo no excerto: "Faltava foco e dedicação?", ele expõe uma tensão que, apesar de se tratar de uma preocupação de caráter afetivo, pode ser também considerada de marca realista de um mundo objetivo. Isso se confirma pela voz de autor empírico na posição social de futuro professor que questiona e aguça o fazer didático-pedagógico.

A vinheta selecionada para nossa última análise é nomeada "Confesso que não sei essa resposta" e estabelece os momentos finais da planificação da SD pelo aluno-professor. As modalizações identificadas serão explanadas em conjunto com o momento de definição das vozes presentes nos excertos, após a apresentação dos SOT e STT. Em relação aos SOTs classificados temos "Socialização em sala de aula" e "As dúvidas continuam". Apresentamos no Quadro 3 os SOTs e STTs desenvolvidos:

Quadro 3 - SOTs/STTs da vinheta: "Confesso que não sei essa resposta"

\begin{tabular}{|c|c|}
\hline $\begin{array}{l}\text { Segmento de } \\
\text { Orientação } \\
\text { Temática (SOT) }\end{array}$ & $\begin{array}{c}\text { Segmento de Tratamento } \\
\text { Temático } \\
\text { (STT) }\end{array}$ \\
\hline $\begin{array}{l}\text { 1) Socialização } \\
\text { em sala de aula }\end{array}$ & $\begin{array}{l}\text { 1.a) Compartilhando trabalhos } \\
\text { 1.b) Diversidade de planificações } \\
\text { 1.c) Comparando informações } \\
\text { 1.d) Dúvidas sanadas } \\
\text { 1.e) Documentos importantes }\end{array}$ \\
\hline $\begin{array}{l}\text { 2) Reflexão do } \\
\text { processo }\end{array}$ & $\begin{array}{l}\text { 2.a) Assimilação de informações } \\
\text { 2.b) Indagações } \\
\text { 2.c) Focando no próximo passo } \\
\text { 2.d) Anseio pelo sucesso }\end{array}$ \\
\hline
\end{tabular}

Fonte: elaboração dos autores.
No primeiro SOT, que fala sobre a "Socialização em sala de aula", vemos em seus STTs a experiência de compartilhamento de trabalhos entre a turma. Essa coparticipação é enriquecedora, pois, como vemos no segundo STT, a diversidade de planificações ajuda o aluno professor a aperfeiçoar sua SD. Conforme vemos no STT seguinte, ao comparar informações é possível um aumento da reflexão no contexto de práticas pedagógicas colaborativas. Quando a reflexão se torna uma experiência compartilhada, é possível obter insights adicionais no processo de ensino-aprendizagem através de um segundo (ou terceiro ou mais) conjunto de lentes. Dessa forma, como diz a próxima STT, dúvidas são sanadas.

Ao descrever a experiência que vivenciou, o aluno-professor esclarece que a "oportunidade de mostrar o trabalho" para o restante da turma é bastante significativa para o seu aprendizado e melhoria de sua percepção quanto ao próprio trabalho. É interessante notarmos a descrição realizada pela aluno-professor rica em detalhes sobre as sugestões de atividades a serem inseridas na SD.

Analisamos no excerto seguinte as vozes e modalizações referentes à vinheta selecionada para este momento de fase final da planificação das SDs.

\section{Excerto 4}

Focando no meu trabalho, nessa reta final recordei de todo o período de aprendizado. $E u$ ainda me via com muitas dúvidas a respeito da produção e tinha muito a melhorar 
em minha SD. Mesmo assim, estava bem otimista, pois a SD começava a fazer sentido para mim e já sabia que não era um simples aglomerado de atividades aleatórias.

Vemos a voz de autor empírico (aluno-professor na posição de pesquisador) no contexto de sala de aula, em que o aluno-professor apresenta uma visão amadurecida de seu processo de planificação da SD, o que se dá pelo fato de o caminho percorrido até então já ter sido bastante significativo. É evidente, também, o uso de formas verbais anteriores e concomitantes ao momento em si: "nessa reta final recordei de todo o período de aprendizado". Enquanto o aluno-professor se coloca no tempo presente da narração por meio do fragmento nessa reta final a ação tomada por ele é de uma retomada reflexiva por meio do verbo recordei, o que poderia indicar que a ação última se trata de uma situação de avaliação de seu percurso.

O aluno-professor prossegue explicando suas tensões e sentimentos, quando começa a compreender todo o sistema de como planificar uma SD, usando inclusive de uma modalização apreciativa no fragmento "o mau tempo começou a se tornar em sábado de sol" para descrever a sua apreensão e compreensão da forma como planificar o conteúdo na SD. Todavia, ainda havia muito a ser questionado, como podemos ver no excerto a seguir:

\section{Excerto 5}

Mesmo assim, muitas questões ainda me intrigam: E se alguém vier a me perguntar se posso dar uma definição ou a função de uma
SD? Agora, após a SD quase pronta e me imaginando aplicando o trabalho em sala de aula, me pergunto o tempo todo: Será que os alunos irão gostar da minha produção? O que é ou não interessante para os alunos? Será que os materiais que estou inserindo em minha SD vão auxiliar os alunos nas situações cotidianas dos mesmos? Como farei com que meu aluno possa vincular o que é estudado com o que o cerca em seu dia?

Podemos observar por meio do trecho me intrigam, uma modalização apreciativa, a qual apresenta a tensão acerca do saber-fazer pedagógico do aluno-professor, visando suas pretensões futuras na própria prática como professor em sala de aula. Deste modo, em consonância com as questões que vêm a seguir no excerto, vemos que, apesar de estar ciente de que seu o trabalho já está encaminhado e prestes a tomar a forma definitiva antes de sua prática, o aluno-professor demonstra dúvidas quanto à como proceder efetivamente com sua SD em um contexto prático de ensino e aprendizagem.

Este segundo excerto consolida a tensão apresentada anteriormente, a qual evidencia as dúvidas do aluno-professor em relação à planificação da sua $\mathrm{SD}$ de uma forma que ela ofereça condições necessárias para que a aprendizagem dos alunos ocorra. Isso é perceptível no trecho me imaginando aplicando o trabalho em sala de aula, o qual sinaliza a voz de autor empírico do aluno-professor que reflete sobre suas aspirações e também dá indícios de que ele busca produzir 
algo de boa qualidade pensando no bem dos alunos. Dessa forma, há um embate entre o que se espera que aconteça e $o$ que é ou pode se tornar realidade.

No trecho "será que os alunos irão gostar da minha produção?”, percebemos, primeiramente, a voz de personagem os alunos e, em seguida, voz de autor empírico na posição social de futuro professor no contexto, embora sendo algo ainda não efetivado, de regente de uma sala de aula. Podemos considerar o fragmento uma modalização lógica por indicar uma necessidade da parte do aluno-professor em compreender o contexto a que será inserido. Nesse ponto há um conflito nas palavras do aluno-professor evidenciando a voz de personagem que remete aos alunos.
Ainda com base nas questões marcadas no excerto, o aluno-professor demonstra estar em uma situação de mão dupla entre o que espera que aconteça e o que possivelmente acontecerá no momento da execução da SD, pois o aluno-professor tem a expectativa de concretizar a planificação da SD da melhor forma possível, mas não vê a possibilidade de fazê-lo devido a não saber como os alunos irão reagir a sua proposta. Desse modo, percebemos a importante necessidade de observação do contexto de sala de aula para uma melhor planificação da SD, o que ajuda a assegurar que a aprendizagem aconteça.

Ademais, observamos algumas das dimensões da planificação elencadas em nossa fundamentação, conforme Quadro 4:

Quadro 4 - Dimensões da planificação da SD

\begin{tabular}{|l|l|}
\hline \multicolumn{1}{|c|}{ Dimensão } & \multicolumn{1}{c|}{ Descrição } \\
\hline Social/interacional & $\begin{array}{l}\text { Observada nas relações estabelecidas com a professora, o mestrando e a } \\
\text { turma de alunos-professores. (excerto 2) }\end{array}$ \\
\hline Prefigurativa /autoprescritiva & $\begin{array}{l}\text { Evidenciada no ato do aluno-professor de fazer um fichamento sobre SDs. } \\
\text { (excerto 1) }\end{array}$ \\
\hline Transpessoal & $\begin{array}{l}\text { Presente na explicitação de que as atividades produzidas servirão para } \\
\text { o ensino em sala de aula, principalmente quando se questiona como o } \\
\text { conteúdo da SD poderá ser relacionado com o que os alunos vivenciam no } \\
\text { dia a dia. (excerto 5) }\end{array}$ \\
\hline Conflituosa & $\begin{array}{l}\text { Evidenciada nas modalizações apreciativas na voz do aluno-professor que } \\
\text { pela primeira vez constrói uma proposta de SD. (excertos 1, 2, 4 e 5) }\end{array}$ \\
\hline Cognitiva & $\begin{array}{l}\text { Exposta a partir do somente que o aluno-professor externaliza que a SD não } \\
\text { é somente "um aglomerado de atividades". (excerto 4) }\end{array}$ \\
\hline Reflexividade & $\begin{array}{l}\text { Trazida nos questionamentos do aluno-professor quanto a como seria sua } \\
\text { prática em sua de aula. (excerto 5) }\end{array}$ \\
\hline Afetiva & $\begin{array}{l}\text { Quando o aluno-professor relembra o processo de construção da SD e se diz } \\
\text { otimista quanto à implementação em sala de aula. (excerto 4) }\end{array}$ \\
\hline
\end{tabular}

Fonte: elaboração dos autores com base em Lanferdini (2019). 


\section{Considerações finais}

Apoiados nos relatos escritos nas vinhetas, buscamos por meio do presente artigo analisar a planificação de uma SD realizada por um aluno-professor de graduação na disciplina de Estágio. Selecionamos três dessas vinhetas, as quais tinham a intenção de mostrar como o complexo sistema de produção de uma SD aparece de maneira concreta numa real situação de trabalho. Dessas vinhetas se originaram cinco excertos, os quais possibilitaram observar os SOTs de desenvolvimento do aluno professor, as tensões, avaliações e saberes que se apresentaram no período de planificação da SD.

Nosso suporte teórico-metodológico se deu em consonância com o ISD. Entre as diferentes tensões que conseguimos averiguar, as de ordem objetiva nos chamam a atenção, pois apontam para conflitos que poderíamos considerar típicos do período de formação docente, os quais revelam as dificuldades de aproximar os conhecimentos aprendidos no momento das aulas de estágio com a prática concreta da planificação da SD. Também são evidenciadas tensões afetivas, como vimos, tais como a angústia narrada pelo aluno-professor nas vinhetas quanto a elaborar uma SD que de fato possibilitasse assegurar a aprendizagem de todos os alunos. Isso tornou evidente as dificuldades encontradas pelo aluno-professor em seu processo de aprendizado, em que são mobilizados seus conhecimentos relevantes e suas tomadas de ações para resolver problemas e atingir objetivos para planificação da SD.

Os resultados demonstram ainda que o aluno professor está em constante transformação e que o Estágio Supervisionado traz etapas de desenvolvimento por meio de experiências vivenciadas gradualmente. Com base nestes resultados iniciais acreditamos que a vinheta é uma ferramenta de avaliação altamente eficaz que proporciona uma rica experiência de aprendizagem para suscitar e promover a compreensão do futuro professor, ou, como noz diz Stutz (2012, p. 59), "a pesquisa voltada para a reflexão sobre a ação ressignifica a ação e é considerada como um ingrediente básico para o aprimoramento profissional".

Finalmente, as evidências deste estudo sugerem que a experiência com vinhetas narrativas oportuniza a conscientização do participante de suas próprias atitudes etnocêntricas. Ou seja, reavaliar seus afazeres e ser consciente de sua aprendizagem, pois tal apreensão ocorre em toda a vida. Assim, vemos que as experiências de aprendizagem mais pungentes geralmente acontecem de forma gradual e em um movimento em espiral de saberes e capacidades docentes referentes à planificação que, por sua vez, se dá por meio de interações entre os pares da formação, a construção de SDs 
e a releitura de textos teóricos, como demonstramos no estudo aqui apresentado.

\section{Analysis of vignettes on didactic sequence planning}

\section{Abstract}

This research aims to analyze vignettes produced in the supervised internship of a third-year class of English language and its literatures, in which a student-teacher registered his experiences during the planification of a didactic sequence (DS). The theoretical support comes from the socio-discursive interactionism and its proposal for didactic transposition of genres and the narrative research. Data generation was carried out between April and June of 2019, through the registration and selection of vignettes on DS production. We considered the contextual aspects, thematic segments, voices and modalizations. The results show that the internship activities in general and the work of reflexivity through narrative vignettes enabled more specific work considering the planification knowledge of classes.

Keywords: Vignettes. Supervised internship. Didactic sequence. Didactic transposition of genres. Planification.

\section{Notas}

Um dos sete saberes que apresentam em sua composição um rol de capacidades docentes a que se visa alcançar com a formação de professores e que têm como base o documento europeu para a formação inicial de professores de línguas estrangeiras: PEPELF - Portfólio europeu para professores de línguas em formação inicial (Portfolio européen pour les enseignants en langues en formation initiale).
2 Gêneros de texto são entendidos como "configurações possíveis dos mecanismos estruturantes da textualidade, portadores de indexações sociais [...], quadros obrigatórios de qualquer produção verbal" (BRONCKART, 2006, p. 145 apud CRISTOVÃO; GAMERO, 2009, p. 231).

3 https:/veraluciacristovao.wordpress.com/.

4 https://www2.unicentro.br/gpgenerostextuais/ ?doing_wp_cron=1596133836.12564992904663 08593750 .

\section{Referências}

BRONCKART, J. P. Atividade de linguagem, textos e discursos: por um sociointeracionismo discursivo. Trad. Anna Raquel Machado e Péricles Cunha. São Paulo: EDUC, 1999/2007.

BRONCKART, J. P. O agir nos discursos: das concepções teóricas às concepções dos trabalhadores. Campinas, SP: Mercado de Letras, 2008.

BRONCKART, J. P. Atividade de linguagem, discurso e desenvolvimento humano. MACHADO, A. R.; MATENCIO, M. L. M (org.). Campinas, SP: Mercado de Letras, 2006.

CACILHO, M. A. Gêneros digitais no ensino de Língua Portuguesa: análise de material apostilado. $158 \mathrm{f}$. Dissertação (Mestrado em Letras) - Universidade Estadual do Centro-Oeste, 2016.

CLANDININ, D. J.; CONNELLY, F. M. Pesquisa narrativa: experiência e história em pesquisa qualitativa. Tradução: Grupo de Pesquisa Narrativa e Educação de Professores ILEEI/UFU. Uberlândia: EDUFU, 2011.

CRISTOVÃO, V. L. L. Gêneros e ensino de leitura em LE: os modelos didáticos de gêneros na construção e avaliação de material didático. Tese (Doutorado em Linguística Aplicada) - Pontifícia Universidade Católica de São Paulo, São Paulo, 2001.

CRISTOVÃO, V. L. L. Sequências didáticas para o ensino de línguas. In: DIAS, R.; CRISTOVÃO, V. L. L. (org.). O Livro Didático 
de Língua Estrangeira: múltiplas perspectivas. Campinas: Mercado de Letras, 2009. p. 305-344.

CRISTOVÃO, V. L. L.; STUTZ, L. Sequências didáticas: semelhanças e especificidades no contexto francófono como L1 e no contexto brasileiro como LE. 2011. In: SZUNDY, P. T. C. et al. (Org.). Linguística aplicada e sociedade: ensino e aprendizagem de línguas no contexto brasileiro. Campinas: Pontes, 2011. p. 17-39.

DOLZ, J.; NOVERRAZ, M.; SCHNEUWLY, B. Sequências didáticas para o oral e a escrita: apresentação de um procedimento. In: DOLZ, Joaquim; SCHNEUWLY, Bernard. Gêneros orais e escritos na escola. Tradução e organização: Roxane Rojo e Glaís Sales Cordeiro. Campinas, SP: Mercado de Letras, 2004.

DOLZ, J.; PASQUIER, A.; BRONCKART, J. P. A aquisição do discurso: emergência de uma competência ou aprendizagem de diferentes capacidades de linguagem? Nonada: Letras em Revista, v. 1, n. 28, p. 156-173, maio 2017/1993.

DOLZ, J. As atividades e os exercícios de língua: uma reflexão sobre a engenharia didática. Delta, São Paulo, v. 32, n. 1, p. 237 260, abr. 2016.

HOELZ, J. C.; BATAGLIA, W. O Uso de Vinhetas em Estudos Qualitativos Análise da aplicação em uma pesquisa da área de Administração. CIAIQ, v. 3, p. 64-69, 2015.

HOFSTETTER, R.; SCHNEUWLY, B. Savoirs en (trans)formation. Au cœur de l'enseignement et de la formation. In: HOFSTETTER, R.; SCHNEUWLY, B. (org.). Savoirs en (trans)formation. Au cœur de l'enseignement et de la formation. Bruxelles: De Boeck, Coll. Raisons Éducatives, 2009. p. 7-40.

LANFERDINI, P. A. F. O planejamento de sequências didáticas no PIBID: espaços para o desenvolvimento do aluno-professor de Língua Inglesa. 2019. 422 f. Tese (Doutorado em Estudos da Linguagem) - Universidade Estadual de Londrina, Londrina, 2019.

LENHARO, R. I. Participação social por meio da música e da aprendizagem de língua inglesa em um contexto de vulnerabilidade social. 2016. 150 f. Dissertação (Mestrado em Estudos da Linguagem) - Universidade Estadual de Londrina, Londrina, 2016.

LIEBERMAN, A. Documenting Professional Practice: The Vignette as a Qualitative Tool. Annual Meeting of the American Educational Research Association, p. 1-14, 1987.

MACHADO, Ana Rachel; BRONCKART, Jean-Paul. (Re-)Configurações do Trabalho do Professor construídas nos e pelos textos: a perspectiva metodológica do Grupo ALTER-LAEL. In: MACHADO, A. R.; ABREU-TARDELLI, L. S.; CRISTOVÃO, V. L. L. (org.). Linguagem e Educação: o trabalho do professor em uma nova perspectiva. Campinas, SP: Mercado de Letras, 2009.

MACHADO, A. R.; CRISTOVÃO, V. L. L. A Construção de Modelos Didáticos de Gêneros: Aportes e Questionamentos para o Ensino de Gêneros. Linguagem em (Dis)curso. Gêneros textuais e ensino-aprendizagem, Tubarão: Unisul, v. 6, n. 3, p. 547-573, set./dez. 2006.

MAGALHÃES, S. M. O. Formação continuada de professores: uma análise epistemológica das concepções postas no Plano Nacional da Educação (PNE 2014-2024) e na Base Nacional Comum Curricular (BNCC). Revista Linhas, Florianópolis, v. 20, n. 43, p. 184-204, maio/ago. 2019.

PAEZ, D.; STUTZ, L. Transposição didática de gêneros textuais. In: IV FÓRUM DAS LICENCIATURAS/VI ENCONTRO DO PIBID/II ENCONTRO PRODOCÊNCIA DIÁLOGOS ENTRE LICENCIATURAS: DEMANDAS DA CONTEMPORANEIDADE. Anais [...]. Irati: 2015. ISSN 2237-1400. Disponível em: http:/www2.unicentro.br/ proen/files/2014/09/Deisiane-Paez-e-Lidia-Stutz.pdf. Acesso em: 15 nov. 2020. 
PIETRO, J.-F. de; SCHNEUWLY, B. Le modèle didactique du genre: un concept de l'ingénierie didactique. Les Cahiers Théodile $\mathrm{n}^{\circ}$ 3: Université Charles-de-Gaulle - Lille 3, jan. 2003, p. 27-53. Tradução de Adair Vieira Gonçalves.

POLEZE, G. A.; STUTZ, L.. Modelização didática do gênero Cantiga de Roda como proposta para o ensino de língua inglesa na Educação Infantil. Revista Horizontes de Linguística Aplicada, v. 18, p. 107-131, 2019. Disponível em <https:/periodicos.unb.br/ index.php/horizontesla/article/view/23668>. Acesso em 14 de junho de 2020.

ROCHA, Décio. Da Linguística Aplicada à didática das línguas: pela diversidade de pesquisas favoráveis ao trabalho com língua estrangeira. Linguagem \& Ensino, Pelotas, v. 19, n. 1, p. 99-123, jan./jun. 2016.

SCHNEUWLY, B. Gêneros e tipos de discurso: considerações psicológicas e ontogenéticas. In: SCHNEUWLY, B.; DOLZ, J. Gêneros orais e escritos na escola. Campinas, SP: Mercado de Letras, 2004.

SCHRATZ, M. et al. The Art and Science of Leading a School. Central5: A Central European View on Competencies for School Leaders: Final report of the Project: International Co-operation for School Leadership Involving Austria, the Czech Republic, Hungary, Slovakia, Slovenia, Sweden, 2013. Budapest: Tempus Public Foundation, 2013.

STUTZ, L.; CRISTOVÃO, V. L. L. Autoconfrontação na formação inicial de professores: um instrumento para reconfigurar saberes docentes. Fólio - Revista De Letras, v. 11, n. 1 2019. Disponível em: https://doi. org/10.22481/folio.v11i1.5114. Acesso em: 15 nov. 2020.

STUTZ, L.; CARNEIRO, F. D. V. Formação docente inicial e continuada: Entre avaliação do agir e configuração de saberes. Eutomia (Recife), v. 1, p. 428-446, 2015. Disponível em <https://periodicos.ufpe.br/revistas/EUTOMIA/article/view/1313>. Acesso em 20 de junho de 2020.
STUTZ, L. Sequências didáticas, socialização de diários e autoconfrontação: instrumentos para a formação inicial de professores de inglês. 2012, 388 f. Tese (Doutorado em Estudos da Linguagem) - Universidade Estadual de Londrina, 2012. 